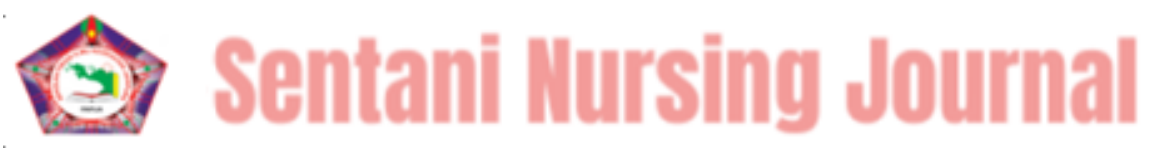

p-ISSN 2615-286X | e-ISSN 2798-5075

DOI 105264637

\title{
HUBUNGAN FUNGSI KOGNITIF DENGAN TINGKAT DEPRESI PADALANSIA DI PANTI BINA LANJUT USIA SENTANI KABUPATEN JAYAPURA
}

\author{
Rahma Dona Yusnita ${ }^{1}$, Mohamad Huri ${ }^{2}$, Arvia $^{3}$ \\ ${ }^{1)}$ Mahasiswa Keperawatan STIKes Jayapura \\ ${ }^{2)}$ LPMP Provinsi Papua \\ ${ }^{3)}$ Prodi S1 Keperawatan Stikes Jayapura \\ email: afnanvia@ymail.com
}

\begin{abstract}
ABSTRAK
Latar belakang: Proses menua dan bertambahnya usia menjadi lebih tua menyebabkan terjadinya penurunan fisik dan psikologis. Penurunan fisik berdampak pada fungsi kognitif lansia yang berdampak pada meningkatkan tingkat depresi pada lansia. Tujuan penelitian: untuk mengetahui hubungan fungsi kognitif dengan tingkat depresi pada lansia di Panti Bina Lanjut Usia Sentani Kabupaten Jayapura. Metode penelitian: Jenis penelitian desktriptif analitik dengan pendekatan cross sectional study yang berlokasi di Panti Bina Lanjut Usia Sentani yang dilaksanakan pada tanggal 17 Mei sampai dengan 12 Juli 2018. sampel dalam penelitian ini adalah lansia sebanyak 49 orang responden. Data diperoleh menggunakan kuesioner MMSE dan kuesioner GDS yang dianalisis menggunakan uji chi square. Hasil penelitian: Secara umum lansia mengalami gangguan fungsi kognitif sebesar 42,9\%, kemungkinan kognitif terganggu sebesar $42,9 \%$ dan fungsi kognitif normal sebesar 14,3\%. Tingkat depresi lansia tertinggi mengalami depresi ringan sebesar 57,1\%, depresi sedang sebesar $24,5 \%$, depresi berat sebesar $10,2 \%$ dan sedikit yang tidak depresi sebesar $8,2 \%$. Hasil uji statistik antara fungsi kognitif lansia dengan tingkat depresi diperoleh $p$ value $=0,028<0,05$. Kesimpulan: Ada hubungan antara fungsi kognitif lansia dengan tingkat depresi pada lansia di Panti Bina Lanjut Usia Sentani Kabupaten Jayapura. Saran: Untuk meningkatkan fungsi kognitif pada lansia, bisa dilakukan dengan banyak membaca serta melakukan kegiatan yang dapat mencegah terjadinya depresi, juga adanya dukungan yang kuat dari perawat, pengelola panti serta keluarga.
\end{abstract}

Kata kunci: Fungsi Kognitif, Tingkat Depresi, Lansia

\section{ABSTRACT}

Background: The process of aging and increasing time becomes older than the physical and psychological deterioration process. Physical decline in cognitive function that has an impact on increased risk in the elderly.

Objective: To know the effect of cognitif funtion with depression scale at Panti Bina Lanjut Usia Sentani Jayapura Regency. Methods: The study was analytic descriptive study with cross sectional study approach that was located at Panti Bina Lanjut Usia Sentani which was held on 17 May - 12 July 2018. The sample 
studied was the elderly of 49 people respondent. Data obtained using MMSE questionnaire and GDS questionnaire were analyzed using pearson product moment. Results: In mostly the elderly with impaired cognitive function as $42.9 \%$, probability cognitive function as $42.9 \%$ and cognitive function is normal as 14.3\%. Highest depression is low depression as 57,1\%, middle depression as $24.5 \%$, weight depression (10.2\%) and non depression as $8.2 \%$. result by statistic between cognitif function with depression elderly by $p$ value $=0,028<$ 0,05. Conclusion: There is relationship between cognitif function with depression scale at Panti Bina Lanjut Usia Sentani Jayapura Regency. Suggestion: To improve cognitive function with a lot of reading as well as doing activities that can prevent the occurrence of depression and nurse, coordinator of panti bina lanjut usia and family support.

Keyword: Cognitif Function, Depression, Elderly

\section{PENDAHULUAN}

Jumlah penduduk lansia di Indonesia mencapai 19,5 juta jiwa atau $8,2 \%$ dari total penduduk. Tahun 2025, jumlah orang lansia diperkirakan $13,2 \%$ dan jadi $25,5 \%$ dari total penduduk 2050 . Jumlah lansia di kota jayapura pada tahun 2012 sebanyak 7660 lansia. Pelayanan terhadap lansia terbagi atas dua yaitu pra lansia yang berumur 45-59 tahun dan lansia untuk berumur diatas 60 tahun. Pada tahun 2012 cakupan pelayanan pra lansia adalah $48,9 \%$ dan lansia $65,3 \%$ (Kementerian Kesehatan RI, 2011). Seseorang yang memasuki usia lanjut umumnya akan terjadi penurunan fungsi kognitif dan psikomotor. Fungsi kognitif yang dimaksud antara lain proses persepsi, belajar, pemahaman, perhatian, pengertian, dan lainlain. (Nataswari, 2018).

Depresi pada lanjut usia merupakan suatu kumpulan gejala yang heterogen mencakup kondisi-kondisi patologis, dan setiap kelainan patologisini memiliki risiko untuk terjadinya dementia (Nugraha, 2018).

Berdasarkan World Health

Organization (WHO), prevalensi keseluruhan kejadian depresi pada lansia secara umum bervariasi antara 10-20\%, hal ini juga tergantung pada situasi budaya di masing-masing daerah di dunia (Bodhare, 2013). Depresi juga dapat menyebabkan peningkatan jumlah disabilitas, terhitung hampir $12 \%$ dari keseluruhan disabilitas. Selain itu, depresi juga secara umum merupakan penyebab utama morbiditas pada fungsi sosial, pekerjaan dan interpersonal (Onya, 2013). Prevalensi kejadian depresi mayor di komunitas pada orang dewasa yang berumur 65 tahun ke atas dikatakan mencapai angka antara $1 \%$ sampai $5 \%$, sementara gejala depresi hampir muncul pada 20\% lansia (Glaesmer, 2011).

Berdasarkan studi pendahuluan yang telah dilakukan di Panti Bina Lanjut Usia Sentani Kabupaten Jayapura pada tanggal 17 Mei 2017 jumlah lansia sebanyak 49 orang. Menurut perawat yang ada di Panti Bina Lanjut Usia Sentani bahwa dari sekian lansia ada yang 
mengalami beberapa gangguan kesehatan yaitu penurunan fungsi kognitif (mudah lupa, sulit memahami suatu perkataan atau kalimat) dan depresi (duduk termenung sendiri dan duduk bersama tapi tidak saling bicara). Dari latar belakang tersebut peneliti tertarik untuk meneliti tentang "Hubungan fungsi kognitif dengan tingkat depresi pada lansia di Panti Bina Lanjut Usia Sentani”.

\section{METODE PENELITIAN}

Jenis penelitian desktriptif analitik dengan pendekatan cross sectional study yang berlokasi di Panti Bina

Lanjut Usia Sentani yang dilaksanakan pada tanggal $17 \mathrm{Mei}$ - 12 Juli 2018. Sampel dalam penelitian ini adalah lansia sebanyak 49 orang responden. Data diperoleh menggunakan kuesioner MMSE dan kuesioner GDS yang dianalisis menggunakan uji chi square.

\begin{tabular}{|c|c|c|}
\hline Tingkat Depresi & $\underline{\mathrm{n}}$ & $\%$ \\
\hline Tidak & 4 & 8,2 \\
\hline depresi & 28 & 57,1 \\
\hline Depresi & 12 & 24,5 \\
\hline Ringan & & $\underline{10,2}$ \\
\hline Depresi Sed & & \\
\hline$\frac{\text { Depresi Berat }}{\text { Jumlah }}$ & 49 & 100 \\
\hline
\end{tabular}

\section{HASIL PENELITIAN}

1. Analisa Univariat

Dalam penyajian analisis univariat dibuat menggunakan tabel, diantaranya meliputi karakteristik responden seperti: usia dan jenis kelamin.

Tabel 1 Karakteristik Responden

Berdasarkan Tabel 1 distribusi karakteristik lansia menurut World
Health Organization (WHO) terbanyak pada kategori lanjut usia tua (75-90 tahun) sebanyak 24 orang (49\%) dan lanjut usia (60-74 tahun) sebanyak 23 orang $(46,9 \%)$ dan kategori lanjut usia tua ( $>90$ tahun) sebanyak 2 orang $(4,1 \%)$. Adapun jenis kelamin lansia terbanyak berjenis kelamin perempuan sebanyak 32 orang $(65,3 \%)$ dan lansia sedikit yang berjenis kelamin laki-laki sebanyak 17 orang $(34,7 \%)$.

Tabel 2 Fungsi Kognitif Lansia

\begin{tabular}{|c|c|c|}
\hline Fungsi Kognitif & $\underline{\mathrm{n}}$ & $\%$ \\
\hline Normal & 7 & 14 \\
\hline Kemungkinan & 2 & 42 \\
\hline gangguankognitif & 1 & 42 \\
\hline Kognitif terganggu & 2 & \\
\hline Jumlah & $\begin{array}{c}1 \\
49\end{array}$ & 10 \\
\hline
\end{tabular}

Berdasarkan Tabel 2 distribusi frekuensi fungsi kognitif dari 49 lansia terbanyak dengan fungsi kognitif terganggu sebanyak 21 orang $(42,9 \%)$, kemungkinan kognitf terganggu sebanyak 21 orang $(42,9 \%)$ dan fungsi kognitif normal sebanyak 7 orang $(14,2 \%)$

\begin{tabular}{|c|c|c|c|c|c|c|c|c|c|}
\hline \multirow{3}{*}{ Fungsi Koggitif } & \multicolumn{8}{|c|}{ Tingkat Depresi } & \multirow{3}{*}{$p$} \\
\hline & \multicolumn{2}{|c|}{$\begin{array}{c}\text { Tidak } \\
\text { Depresi }\end{array}$} & \multicolumn{2}{|c|}{$\begin{array}{l}\text { Depresi } \\
\text { Ringan }\end{array}$} & \multicolumn{2}{|c|}{$\begin{array}{l}\text { Depresi } \\
\text { Sedang }\end{array}$} & \multicolumn{2}{|c|}{$\begin{array}{l}\text { Depresi } \\
\text { Berat }\end{array}$} & \\
\hline & I & $\%$ & II & $\%$ & II & $\%$ & in & $\%$ & \\
\hline 1.Normal & 1 & 14,3 & 4 & 57,1 & 1 & 14,3 & 1 & 14,3 & \\
\hline 2. Kemungkinan gg kognitif & 2 & 9,5 & 17 & 81 & 1 & 4,8 & 1 & 4.8 & 0,028 \\
\hline 3. Gangguan koginitif & 1 & 4.8 & 7 & 33,3 & 10 & 47.6 & 3 & 14,3 & \\
\hline
\end{tabular}

\begin{tabular}{lcc}
\hline \multicolumn{1}{c}{ Karakteristik } & $\mathrm{n}$ & $\%$ \\
\hline Usia & & \\
60-74 tahun & 23 & 46,9 \\
$75-90$ tahun & 24 & 49 \\
$>90$ tahun & 2 & 4,1 \\
\hline Jumlah & 49 & 10 \\
& & 0 \\
\hline Jenis Kelamin & & \\
$\quad$ Laki - & 17 & 34,7 \\
$\quad$ laki & 32 & 65,3 \\
$\quad$ Perempu & & \\
$\quad$ an & & \\
\hline Jumlah & 49 & 10 \\
& & 0 \\
\hline
\end{tabular}

Tabel 3 DistribusiResponden Menurut 
Berdasarkan Tabel 3 distribusi frekuensi tingkat depresi dari 49 orang lansia tertinggi mengalami depresi ringan sebanyak 28 orang $(57,1 \%)$, depresi sedang sebanyak 12 orang $(24,5 \%)$, depresi berat sebanyak 5 orang $(10,2 \%)$, sedangkan lansia yang tidak depresi sebanyak 4 orang $(8,2 \%)$

\section{Analisa Bivariat}

Tabel 4 Hubungan Fungsi Kognitif Dengan Tingkat Depresi Pada Lansia Tabel 4 menunjukkan bahwa lansia dengan fungsi kognitif normal terbanyak dengan depresi ringan sebanyak 4 orang $(57,1 \%)$. Lansia yang kemungkinan gangguan kognitif terbanyak dengan depresi ringan sebanyak 17 orang $(81 \%)$, lansia yang dengan gangguan fungsi kognitif terbanyak dengan depresi sedang sebanyak 10 orang $(47,6 \%)$.

Lansia yang mengalami depresi berat terbanyak pada lansia dengan gangguan fungsi kognitif sebanyak 3 orang (14,3\%). Hasil uji pearson chi squarediperoleh nilai $\mathrm{p}=0,028<\square=0,05$ yang dinyatakan ada hubungan antara fungsi kognitif lansia dengan tingkat depresi pada lansia di Panti Bina Lanjut Usia Sentani Kabupaten Jayapura.

\section{PEMBAHASAN}

\section{Fungsi kognitif pada lansia} Kognitif merupakan kemampuan pengenalan dan penafsiran seseorang terhadap lingkungan berupa perhatian, bahasa, memori dan fungsi memutuskan, sehingga mengganggu aktifitas hidup sehari-hari dan aktifitas sosial. Penurunan dari fungsi kognitif biasanya berhubungan dengan penurunan fungsi belahan kanan otak yang berlangsung lebih cepat dari pada yang kiri. Kemunduran kognitif pada lansia biasanya diawali dengan kemunduran memori atau daya ingat (pelupa) dan daya pikir lain yang secara nyata mengganggu aktivitas kehidupan (Aini, 2016).

Hasil penelitian ini sejalan yang dilakukan Aini (2016) pada lansia di Kelurahan Barusari Kecamatan Semarang Selatan bahwa sebanyak $5,8 \%$ lansia dengan fungsi kognitif normal.

Penelitian yang dilakukan dari 49 orang lansia di Panti Bina Lanjut Usia di Sentani Kabupaten Jayapura menggunakan kuesioner MMSE diperoleh terbanyak dengan fungsi kognitif terganggu sebanyak 21 orang $(42,9 \%)$

Menurut Bennet dalam Wreksoatmodjo (2013), hal ini disebabkan bahwa aspek proses kognitif yang membangun dan mempertahankan jaringan sosial juga dapat berlaku sebagai cadangan terhadap risiko gangguan kognitif akibat adanya akumulasi patologi jaringan otak atau dengan mengkompensasi efek degenerasi sistem kognitif non sosial.Rekrutmen area otak alternatif sebagai respon terhadap kerusakan akibat penuaan dan degenerasi telah banyak tercatat dalam studipencitraan. Misalnya, penuaan diasosiasikan dengan peningkatan area otak yang pada orang muda tidak aktif. Pola ini dianggap menggambarkan kompensasi terhadapkerusakan yang berhubungan dengan penuaan melalui jaringan neural alternatif.

Lansia di Panti Bina Lanjut Usia di Sentani Kabupaten Jayapura yang mengalami kemungkinan kognitif terganggu sebanyak 21 orang $(42,9 \%)$. Lansia yang mengalami kemungkinan kognitif terganggu pada aspek perhatian dan kalkulasi dimana lansia diminta menyebut terbalik kata 
"dunia" (terbalik= ainud. Menurut Stanley \& Berae dalam Aini (2016) lansia yang mengalami gangguan fungsi kognitif pada tahapan ini terjadi gangguan memori sedang yang merupakan gangguan memori, berhitung danaktifitas spontanmenurun, dimana lansia tersebut masih mengingat beberapa bagian dari masa lalu yang diingatnya dan tidak mengganggu pada aktifitas rutin yang dilakukan.

Menurut Potter \& Perry (2012), beberapa faktor yang mempengaruhi lansia yang mengalami gangguan fungsi kognitif didalam kualitas hidupnya dalam pemenuhan aktivitas sehari-hari antara lain, umur dan jenis kelamin. Hasil penelitian pada lansia di Panti Bina Lanjut Usia di Kabupaten Jayapura, lansia yang mengalami gangguan fungsi kognitif tertinggi pada usia > 90 tahun sebanyak 1 orang $(50 \%)$ dan usia 75-90 tahun sebanyak 14 orang $(58,3 \%)$ sedangkan gangguan fungsi kognital terendah pada lansia yang berumur 60-74 tahun sebanyak 6 orang $(26,1 \%)$. Hal ini menunjukkan semakin bertambahnya usia fungsi kognitif semakin menurun.

Penelitian ini sejalan yang dilakukan Pinilih (2015), bahwa fungsi kognitif terganggu atau fungsi kognitif berat tertinggi pada usia lansia di atas 75 tahun. Kondisi fungsikognitif pada lansia ini sesuai dengan teoridari Sugarman (2006, dalam Trihayati, 2016) yang menyebutkan bahwafungsi kognitif menurun di usia tua karenapenurunan jumlah neuron, penurunanukuran otak dan berat otak berkurang.

Berdasarkan jenis kelamin, gangguan fungsi kognitif pada lansia yang berjenis kelamin laki-laki sebanyak 8 orang $(47,1 \%)$ sedangkan pada lansia yang berjenis kelamin perempuan sebanyak 13 orang $(40,6 \%)$. Penelitian ini sejalan yang dilakukan sebelumnya oleh Trihayati (2016), bahwa lansia perempuan banyak yangmengalami gangguan kognitif dibandingkan dengan lansia laki-laki. Pernyataan ini didukung oleh Myers (2008 dalam Pathia, 2015) yang menyatakan bahwa wanita lebih berisiko mengalami penurunan kognitif dari pada laki-laki. Penurunan kognitif pada wanitadisebabkan adanya peranan level hormon seks endogen dalam perubahan fungsi kognitif.

a. Tingkat depresi pada lansia Depresi merupakan gangguan psikiatri yang paling sering terjadi pada lansia, hal ini terjadi akibat dari interaksi faktor biologi, fisik, psikologi dan sosial. menyebutkan depresi adalah salah satu gangguan mood, dimana terjadi perubahan kondisi emosional, motivasi, fungsi dan perilaku motorik serta kognitif pada diri seseorang. Seseorang yang mengalami depresi akan mengalami perubahan dalam bentuk pemikiran, sensasi somatik, aktivitas, serta kurang produktif dalam pengembangan pikiran berbicara dan sosialisasi (Kusumowardani, 2014).

Hasil peneiltian diperoleh bahwa tingkat depresi pada lansia di Panti Bina Lanjut Usia Sentani Kabupaten Jayapura dari 49 orang lansia tertinggi mengalami depresi ringan sebanyak 28 orang $(57,1 \%)$. Lansia yang mengalami depresi ringan disebabkan lansia merasa hampa, tidak memiliki semangat yang baik sepanjang waktu dan merasa tidak berharga saat ini. tanggapan lansia. Hasil penelitian in sejalan yang dilakukan Nauli (2014), bahwa lansia dengan depresi sedang merasa hampa dan merasa dirinya sudah tidak berharga lagi.

Menurut Miller (2004 dalam 
Nataswari, 2018) pada lansia dengan adanya penurunan fisik menyebakan kesepian akibat kurangnya interaksi sosial yang menyebabkan kesepian pada diri lansia dan menimbulkan permasalahan status dan memberikan pengaruh terhadap kemampuan aktivitas sehari-hari pada lansia menyebabkan harga diri yang menurun, perasaan hampa dan perasaan negatif terhadap diri sendiri.

Kaum lansia sering dianggap tidak berdaya, sakit sakitan, tidak produktif, sehingga kehidupan lansia menjadi kurang bermakna, maka jangan heran kalau melihat para lansia tampak lesu, tidak bergairah, merasa tidak dihargai dalam kehidupannya sehingga cepat merasa tua. (Aini, 2016). Menurut Maryam (2008, dalam Nataswari, 2018) sebenarnya lanjut usia dapat dikatakan usia emas, karena tidak semua orangdapat mencapai usia tersebut, maka orang yangberusia lanjut memerlukan tindakan keperawatan, baik yang bersifat promotif maupun preventif, agar lansia dapat menikmati masa usia emas serta menjadi lansia yang berguna dan bahagia.

Menurut Wreksoatmodjo (2013), aktivitas yang dilakukan bermanfaat untuk membuang beban kondisi psikologis seseorang dengan perasaan yang lebih menyenangkan selain itu dengan kagiatan yang disenangi lansia dapat membuat lansia tidak memikirkan hal - hal negatif yang menambah stres. keterbatasan ini membuat lansia semakin tidak berdaya dan lebih senang menyendiri.

Lansia di Panti Bina Lanjut Usia Sentani Kabupaten Jayapura yang tidak mengalami depresi proporsinya lebih sedikit sebanyak 4 orang $(8,2 \%)$ disebabkan lansia menerima dengan keadaan dirinya yang sudah bersuai lanjut. Penelitan ini juga sejalan yang dilakukan Kusumowardani (2014) yang menyebutkan bahwa sebayak 5\% lansia tidak mengalami depresi. Hal ini menunjukan bahwa umumnya semakin bertambah usia semakin tinggi tingkat depresi yang dialami seseorang dan tergantung dari tingkat penerimaan seseorang dengan perubahan diri menjadi tua.

\section{Hubungan fungsi kognitif dengan tingkat depresi pada lansia}

Penurunan fungsi kognitif pada lansia merupakan penyebab terbesar terjadinya ketidakmampuan dalam melakukan aktivitas normal sehari-hari dan juga merupakan alasan tersering yang menyebabkan terjadinya ketergantungan terhadap orang lain untuk merawat diri sendiri (care dependence) pada lansia. Pengetahuan atau kognitif diperlukan untukmemenuhi kebutuhan lansia dan sikap juga dapat mempengaruhi perilaku lansia terhadap tingkat depresi (Zaskia, 2012).

Hasil penelitian diperoleh bahwa lansia dengan fungsi kognitif normal yang tidak mengalami depresi sebanyak 1 orang (14,3\%), sedangkan yang mengalami depresi ringan sebanyak 4 orang $(57,1 \%)$, depresi sedang sebanyak 1 orang $(14,3 \%)$ dan depresi berat sebanyak 1 orang $(14,3 \%)$. Hal ini sejalan yang dilakukan Kusumowardani (2014), bahwa lansia dengan fungsi kognitif normal sebagian besar mengalami depresi ringan.

Pada penelitian ini juga ditemukan lansia yang kemungkinan gangguan kognitif terbanyak mengalami depresi ringan sebanyak 
17 orang (81\%) dan lansia yang mengalami gangguan fungsi kognitif terbanyak mengalami depresi sedang sebanyak 10 orang $(47,6 \%)$. Hal ini menunjukkan bahwa semakin tinggi fungsi kognitif terganggu semakin tinggi depresi yang dialami oleh lansia. Hal ini juga dibuktikan dari hasil $p$ value $=0,028$ yang dinyatakan ada hubungan fungsi kognitif lansia dengan tingkat depresi pada lansia di Panti Bina Lanjut Usia Sentani Kabupaten Jayapura.

\section{KESIMPULAN}

Berdasarkan hasil penelitian hubungan fungsi kognitif dengan tingkat depresi pada lansia di Panti Bina Lanjut Usia Sentani dapat disimpulkan sebagai berikut; secara umum lansia mengalami fungsi kognitif terganggu $(42,9 \%)$ dan kemungkinan kognitif terganggu $(42,9 \%)$ dan sedikit dengan fungsi kognitif normal $(14,2 \%)$. Tingkat depresi lansia tertinggi mengalami depresi ringan $(57,1 \%)$, depresi sedang $(24,5 \%)$, depresi berat $(10,2 \%)$ dan sedikit yang tidak depresi (8,2\%). Ada hubungan antara fungsi kognitif lansia dengan tingkat depresi pada lansia di Panti Bina Lanjut Usia Sentani Kabupaten Jayapura ( $p$-value $=$ 0,028).

\section{DAFTAR PUSTAKA}

Aini DW. 2016.Hubungan Fungsi Kognitif Dengan Kualitas Hidup Pada Lansia Di Kelurahan Barusari Kecamatan Semarang Selatan. P- ISSN: 2086-3071, E-ISSN: $2443-$ 0900. Volume 7, Nomor 1, Januari 2016http://ejournal.umm.ac.id/ind ex.php/ke

perawatan/issue/view.diakses 15 Juli 2018.

Amir N. 2005. Depresi: Aspek Neurobiologi Diagnosis dan Tatalaksana. Jakarta: Balai Penerbit FKUI.

Bhayu Agus, 2014. Gambaran faktor-faktor yang mempengarhi Tingkat Depresi pada Lanjut Usia Di Wilayah Kerja Puskesmas Kubu II.

Bodhare TN, Kaushal V, VenkateshK, Kumar MA (2013). Prevalence and risk factors of depression among elderlypopulation in rural area. Perspective in Medical Research. India. 2013;1(1): 11- 15

Glaesmer H, Rieder-Heller S,Braehler E, Spangenberg L, Luppa M. 2011. Age- and gender-specific prevalenceand risk factors for depressivesymptoms in the elderly: al3population-based study. International Psychogeriatric Association. 2011; 1-7

Goldman, H.H., 2000. Rivew of general psychiatri: An Introduction to Clinical Medicine.

Handayani, ZM.. 2014. Hubungan Peran Keluarga Dengan Pemenuhan Kebutuhan Perawatan Diri Pada Lanjut Usia di Dusun Jogonalan Lor Kasihan Bantul.

http://www.stikesaisyah.co.id. diakses 2 Mei2017.

Kementrian Kesehatan RI 2011. Kecakapan \& pengasuhan lansia. Jakarta: Depkes RI

Kusmiarto. 2013. Gambaran Diri Tidak Berhubungan dengan Tingkat Depresi pada Lansia di UPT Panti Wredha Budhi Dharma 
Yogyakarta. Journal NersAnd Midwifery Indonesia.JNKI, Vol. 1, No. 1, Tahun 2013, 18-22.

Kusumowardani A. 2014. Hubungan Antara Tingkat Depresi Lansia Dengan Interaksi Sosial Lansia di Desa Sobokerto Kecamatan Ngemplak Boyolali. Jurnal Terpadu Ilmu Kesehatan, Volume 3, No 2, November 2014, hlm 106-214.

Lanawati, 2015 Hubungan Antara Senam Kesegaran Jasmani Lansia Dengan Fungsi Kognitif dan Keseimbangan Tubuh Di Posyandu Lansia Desa Dauh Puri Kauh Denpasar. http://www.unud.co.id. diakses 15 Juli 2018.

Nataswari PP. 2018. Hubungan dukungan keluarga dengan depresi pada lansia di Panti Sosial Werdha Wana SerayaDenpasar Bali. E-Jurnal Medika Vol 7 No 2 Februari 2018 -45-59.

Nauli. 2014. Hubungan Tingkat Depresi Dengan Tingkat Kemandirian Dalam Aktifitas Sehari-Hari Pada Lansia Di Wilayah Kerja Puskesmas Tembilahan Hulu.

Metodologi Penelitian

Kesehatan. Jakarta: Rineka Cipta.

Nugraha IBA. 2018. Korelasi Depresi Terhadap Penurunan

Padila. 2013. Buku Ajar Keperawatan Gerontik. Dilengkapi Aplikasi Kasus Asuhan Keperawatan Gerontik dan Sesuai Kompetensi Standar. Jakarta: Nuha Medika.

Pathia C. 2015. Hubungan Dukungan Sosial Dengan Fungsi Kognitif Pada Lansia di Kelurahan Ganting Andalas Padang. http://www.unand.co.id. diakses 15 Juli 2018.
Pinilih SS. 2015. Hubungan Antara Lifestyle Dengan Fungsi Kognitif Pada Lansia. Universitas Muhammadiyah Magelang. diakses 15 Juli 2018.

Potter \& Perry. 2012. Fundamental Keperawatan, Edisi 2, ECG, Jakarta

Ratnasari. 2014. Efektivitas Penerapan Komunikasi Terapeutik Keluarga Terhadap Status Harga Diri Lansia. http://www.akperhusada.co.id. diakses 2 April 2018

Sherry GA. 2012. The Geatric Depression Scale. http://eprints.ums.ac.id/ 3677/4.pdf. diakses 5 Maret 2018.

Trihayati N. 2016. Hubungan Fungsi Kognitif Dengan Tingkat Kemandirian Aktivitas SehariHari Pada Lansia di UPT Panti Wredha Budhi Dharma Ponggalan

World Health Organization. 2015. World Report on Agieng and Health

Wreksoatmodjo BR. 2013. Pengaruh Sosial Engagement terhadap FungsiKognitif Lanjut Usia di Jakarta. Bagian Neurologi, Fakultas Kedokteran Universitas Katolik Atmajaya,Jakarta, Indonesia. $C D K$ 214/ vol. 41 no. 3,th. 2014.

Zaskia, Y. 2012. Faktor Faktor yang Mempengaruhi Perilaku Lansia dalam Kemandirian Pemenuhan Kebutuhan ADL di Panti SosialTresna Werdha Budi Mulia 4 Marga guna Jakarta Selatan dalam

http://digilib.esaunggul.ac.iddiaks es tgl19juli2018 